\title{
ROLE OF ORAL GLYCEROL IN GLAUCOMA*
}

\author{
BY \\ P. AWASTHI AND S. N. SRIVASTAVA \\ Department of Ophthalmology, 'Sarojni Naidu Medical College, Agra, India
}

IN cases of acute glaucoma the aim is to reduce the raised ocular tension in the shortest possible time. If the tension is controlled, a complete examination of the angle is possible and a planned operation can be done. In order to reduce ocular tension various drugs have been used in the past. A recently introduced drug is oral glycerol, a hypertonic solution with strong osmotic properties. It has been tried by Virno, Cantore, Bietti, and Bucci (1963), Casey and Trevor-Roper (1963), Thomas (1963), and Drance (1964). This study was carried out to compare the effect of oral glycerol and Diamox (acetazolamide) in acute congestive glaucoma. These two drugs were also combined with pilocarpine.

\section{Materials and Method}

Patients for this study were selected from the ophthalmic wards of Sarojni Naidu Hospital, Agra. The cases were divided into the following two groups:

(I) Normal Cases.-These cases include nurses, a few ward boys, and cataract patients.

(II) Acute Glaucoma Cases.-

(A) Acute glaucoma treated with oral glycerol.

(B) Acute glaucoma treated with Diamox only.

(C) Acute glaucoma treated with Diamox and pilocarpine drops.

(D) Acute glaucoma treated with oral glycerol and Diamox.

(E) Acute glaucoma treated with oral glycerol, Diamox, and pilocarpine drops.

Dosage.-Glycerol was given in doses of $1.5 \mathrm{~g}$. per $\mathrm{kg}$. body-weight mixed with an equal volume of normal saline to make a 50 per cent. solution, orange juice was added, and the mixture cooled to $3^{\circ}-5^{\circ} \mathrm{C}$. Ocular tension was taken before the administration of glycerol. Subsequently the tension was recorded every hour for $\mathbf{4}$ hours and 4 -hourly for 72 hours.

\section{Observations}

The effect of the drug was studied in 38 control eyes and in 57 eyes suffering from acute glaucoma.

* Received for publication September 9, 1964. 


\section{Group I}

The effect on 38 normal eyes was studied. In all cases there was a fall in ocular tension. The maximum fall occurred at the end of the first hour, the tension gradually regaining the pre-treatment level at the end of the fourth hour. There was no rebound rise in tension. The normal cases were divided into two groups:

(a) Patients over 40 years old-33 patients.

(b) Patients less than 40 years old-5 patients.

Tension in the normal patients ranged from 12 to $24 \mathrm{~mm}$. Hg. The average fall of tension in the first hour was $8 \mathrm{~mm}$. Hg in the eyes of patients 40 years and over and $10 \mathrm{~mm} . \mathrm{Hg}$ in those aged less than 40 years, and the average percentage fall of tension in the over- 40 age-group was 47 per cent. and in the less than 40 age-group it was 49 per cent. (Tables I and II).

TABLE I

Fall of Tension in Normal Eyes in Patients over 40 Years

(RANGE 12-24 MM. HG)

\begin{tabular}{|c|c|c|c|c|c|c|c|c|c|}
\hline \multirow[b]{2}{*}{$\begin{array}{c}\text { Age } \\
\text { (yrs) }\end{array}$} & \multirow[b]{2}{*}{ Sex } & \multirow[b]{2}{*}{ Eye } & \multicolumn{7}{|c|}{ Ocular Tension } \\
\hline & & & Zero hr & $1 \mathrm{hr}$ & $2 \mathrm{hrs}$ & $3 \mathrm{hrs}$ & $4 \mathrm{hrs}$ & $\begin{array}{c}\text { Fall in } \\
\text { Tension } \\
\text { in first } \mathrm{hr} \\
(\mathrm{mm} . \mathrm{Hg})\end{array}$ & $\begin{array}{l}\text { Percentage } \\
\text { Fall in } \\
\text { Tension } \\
\text { in first hr }\end{array}$ \\
\hline $\begin{array}{l}55 \\
60 \\
50 \\
55 \\
47 \\
65 \\
50 \\
40 \\
55 \\
44 \\
55 \\
50 \\
45 \\
55 \\
60 \\
60 \\
65 \\
45 \\
46 \\
50 \\
65 \\
65 \\
40 \\
52 \\
60 \\
50 \\
45 \\
45 \\
50 \\
55 \\
50\end{array}$ & $\begin{array}{l}\mathbf{M} \\
\mathbf{M} \\
\mathbf{M} \\
\mathbf{M} \\
\mathbf{M} \\
\mathbf{M} \\
\mathbf{M} \\
\mathbf{M} \\
\mathbf{M} \\
\mathbf{M} \\
\mathbf{M} \\
\mathbf{F} \\
\mathbf{F} \\
\mathbf{M} \\
\mathbf{M} \\
\mathbf{M} \\
\mathbf{M} \\
\mathbf{M} \\
\mathbf{M} \\
\mathbf{M} \\
\mathbf{M} \\
\mathbf{M} \\
\mathbf{F} \\
\mathbf{F} \\
\mathbf{F} \\
\mathbf{F} \\
\mathbf{F} \\
\mathbf{M} \\
\mathbf{M} \\
\mathbf{F} \\
\mathbf{M}\end{array}$ & $\begin{array}{l}\mathbf{R} \\
\mathbf{R} \\
\mathbf{R} \\
\mathbf{L} \\
\mathbf{R} \\
\mathbf{L} \\
\mathbf{R} \\
\mathbf{L} \\
\mathbf{R} \\
\mathbf{R} \\
\mathbf{R} \\
\mathbf{R} \\
\mathbf{R} \\
\mathbf{R} \\
\mathbf{R} \\
\mathbf{L} \\
\mathbf{L} \\
\mathbf{R} \\
\mathbf{L} \\
\mathbf{L} \\
\mathbf{L} \\
\mathbf{R} \\
\mathbf{R} \\
\mathbf{R} \\
\mathbf{L} \\
\mathbf{L} \\
\mathbf{L} \\
\mathbf{L} \\
\mathbf{L} \\
\mathbf{L} \\
\mathbf{R} \\
\mathbf{R} \\
\mathbf{R} \\
\mathbf{R} \\
\mathbf{L} \\
\mathbf{R}\end{array}$ & $\begin{array}{l}17 \\
18 \\
18 \\
16 \\
17 \\
17 \\
17 \\
17 \\
16 \\
17 \\
17 \\
18 \\
12 \\
18 \\
17 \\
20 \\
22 \\
20 \\
22 \\
19 \\
24 \\
22 \\
19 \\
20 \\
20 \\
22 \\
22 \\
20 \\
21 \\
18 \\
18 \\
17 \\
20\end{array}$ & $\begin{array}{r}8 \\
10 \\
8 \\
7 \\
7 \\
7 \\
8 \\
5 \\
4 \\
10 \\
11 \\
7 \\
12 \\
12 \\
6 \\
12 \\
16 \\
14 \\
12 \\
14 \\
10 \\
12 \\
7 \\
99 \\
55 \\
12 \\
15 \\
15 \\
10 \\
10 \\
12 \\
8 \\
15\end{array}$ & $\begin{array}{r}8 \\
8 \\
8 \\
7 \\
10 \\
8 \\
8 \\
8 \\
8 \\
12 \\
11 \\
8 \\
10 \\
12 \\
10 \\
18 \\
10 \\
9 \\
19 \\
12 \\
8 \\
12 \\
10 \\
12 \\
12 \\
18 \\
15 \\
15 \\
15 \\
8 \\
12 \\
8 \\
15\end{array}$ & $\begin{array}{l}14 \\
12 \\
13 \\
11 \\
14 \\
15 \\
12 \\
10 \\
12 \\
15 \\
15 \\
10 \\
10 \\
14 \\
15 \\
18 \\
16 \\
14 \\
15 \\
14 \\
15 \\
17 \\
14 \\
17 \\
14 \\
20 \\
19 \\
16 \\
18 \\
12 \\
14 \\
14 \\
16\end{array}$ & $\begin{array}{l}17 \\
17 \\
18 \\
16 \\
17 \\
17 \\
16 \\
18 \\
12 \\
15 \\
16 \\
18 \\
12 \\
16 \\
17 \\
20 \\
20 \\
18 \\
20 \\
19 \\
22 \\
20 \\
19 \\
19 \\
20 \\
21 \\
20 \\
18 \\
20 \\
17 \\
16 \\
17 \\
18\end{array}$ & $\begin{array}{r}9 \\
8 \\
10 \\
9 \\
10 \\
10 \\
9 \\
12 \\
12 \\
7 \\
6 \\
11 \\
0 \\
6 \\
11 \\
8 \\
6 \\
6 \\
10 \\
5 \\
14 \\
10 \\
13 \\
12 \\
15 \\
10 \\
7 \\
5 \\
11 \\
8 \\
6 \\
9 \\
5\end{array}$ & $\begin{array}{l}52 \\
44 \\
56 \\
58 \\
52 \\
52 \\
52 \\
70 \\
70 \\
44 \\
33 \\
35 \\
0 \\
33 \\
35 \\
50 \\
27 \\
30 \\
45 \\
26 \\
70 \\
45 \\
63 \\
55 \\
68 \\
45 \\
31 \\
25 \\
52 \\
44 \\
33 \\
52 \\
25\end{array}$ \\
\hline
\end{tabular}

Average fall, $8 \mathrm{~mm}$. $\mathrm{Hg}$ in first hour. 
TABLE II

Fall of Tension in Normal Eyes in Patients less than 40 Years

\begin{tabular}{|c|c|c|c|c|c|c|c|c|c|}
\hline \multirow[b]{2}{*}{$\begin{array}{c}\text { Age } \\
\text { (yrs) }\end{array}$} & \multirow[b]{2}{*}{ Sex } & \multirow[b]{2}{*}{ Eye } & \multicolumn{7}{|c|}{ Ocular Tension } \\
\hline & & & Zero hr & $1 \mathrm{hr}$ & $2 \mathrm{hrs}$ & $3 \mathrm{hrs}$ & $4 \mathrm{hrs}$ & $\begin{array}{l}\text { Fall in } \\
\text { Tension } \\
\text { in first } \mathrm{hr} \\
(\mathrm{mm} . \mathrm{Hg})\end{array}$ & $\begin{array}{l}\text { Percentage } \\
\text { Fall in } \\
\text { Tension } \\
\text { in first } \mathrm{hr}\end{array}$ \\
\hline $\begin{array}{l}25 \\
20 \\
20 \\
28 \\
35\end{array}$ & $\begin{array}{l}\mathbf{M} \\
\mathbf{F} \\
\mathbf{F} \\
\mathbf{M} \\
\mathbf{M}\end{array}$ & $\begin{array}{l}\mathbf{R} \\
\mathbf{L} \\
\mathbf{L} \\
\mathbf{L} \\
\mathbf{R}\end{array}$ & $\begin{array}{l}18 \\
20 \\
22 \\
15 \\
20\end{array}$ & $\begin{array}{r}10 \\
10 \\
10 \\
5 \\
10\end{array}$ & $\begin{array}{l}12 \\
12 \\
15 \\
10 \\
10\end{array}$ & $\begin{array}{l}14 \\
15 \\
15 \\
10 \\
15\end{array}$ & $\begin{array}{l}16 \\
18 \\
20 \\
15 \\
15\end{array}$ & $\begin{array}{r}8 \\
10 \\
12 \\
10 \\
10\end{array}$ & $\begin{array}{l}44 \\
50 \\
54 \\
50 \\
50\end{array}$ \\
\hline
\end{tabular}

Average fall, $10 \mathrm{~mm}$. $\mathrm{Hg}$ in first hour.

Average percentage fall, 49 per cent. in first hour.

\section{Group II}

(A) Acute glaucoma treated with oral glycerol.

Fifteen eyes suffering from acute glaucoma were treated. It was observed that the maximum fall in tension occurred in the first hour. There was complete relief from all the symptoms except congestion of the eye. This group was divided into two further groups, depending upon the initial tension:

(1) Tension between 48 and $60 \mathrm{~mm} . \mathrm{Hg}-10$ eyes.

(2) Tension between 61 and $76 \mathrm{~mm}$. $\mathrm{Hg}-5$ eyes.

In group 1 the average fall of tension that occurred in the first hour was $35 \mathrm{~mm} . \mathrm{Hg}$ and the percentage fall was 65 per cent. (Table III).

TABLE III

Fall in Tension in Patients with Acute Glaucoma treated with Oral Glycerol (RANGE OF TENSION, 48-60 MM. HG)

\begin{tabular}{|c|c|c|c|c|c|c|c|c|c|}
\hline \multirow[b]{2}{*}{$\begin{array}{c}\text { Age } \\
\text { (yrs) }\end{array}$} & \multirow[b]{2}{*}{ Sex } & \multirow[b]{2}{*}{ Eye } & \multicolumn{7}{|c|}{ Ocular Tension } \\
\hline & & & Zero $\mathrm{hr}$ & $1 \mathrm{hr}$ & $2 \mathrm{hrs}$ & $3 \mathrm{hrs}$ & $4 \mathrm{hrs}$ & $\begin{array}{c}\text { Fall in } \\
\text { Tension } \\
\text { in first } \mathrm{hr} \\
(\mathrm{mm} . \mathrm{Hg})\end{array}$ & $\begin{array}{l}\text { Percentage } \\
\text { Fall in } \\
\text { Tension } \\
\text { in first hr }\end{array}$ \\
\hline $\begin{array}{l}65 \\
50 \\
60 \\
38 \\
35 \\
65 \\
40 \\
42 \\
50 \\
60\end{array}$ & $\begin{array}{l}\mathbf{F} \\
\mathbf{M} \\
\mathbf{F} \\
\mathbf{F} \\
\mathbf{M} \\
\mathbf{F} \\
\mathbf{F} \\
\mathbf{M} \\
\mathbf{M} \\
\mathbf{F}\end{array}$ & $\begin{array}{l}\text { L } \\
\text { L } \\
\text { L } \\
\text { L } \\
\text { L } \\
\text { R } \\
\text { R } \\
\text { R } \\
\text { L } \\
\text { L }\end{array}$ & $\begin{array}{l}55 \\
55 \\
48 \\
58 \\
57 \\
60 \\
58 \\
49 \\
48 \\
50\end{array}$ & $\begin{array}{l}19 \\
20 \\
18 \\
19 \\
16 \\
22 \\
16 \\
25 \\
14 \\
15\end{array}$ & $\begin{array}{l}22 \\
20 \\
16 \\
25 \\
18 \\
20 \\
16 \\
20 \\
20 \\
18\end{array}$ & $\begin{array}{l}23 \\
22 \\
20 \\
28 \\
18 \\
20 \\
18 \\
18 \\
22 \\
20\end{array}$ & $\begin{array}{l}28 \\
25 \\
28 \\
28 \\
20 \\
25 \\
20 \\
25 \\
22 \\
20\end{array}$ & $\begin{array}{l}36 \\
35 \\
30 \\
39 \\
41 \\
38 \\
42 \\
24 \\
34 \\
35\end{array}$ & $\begin{array}{l}65 \\
63 \\
62 \\
67 \\
71 \\
63 \\
72 \\
48 \\
70 \\
70\end{array}$ \\
\hline
\end{tabular}

Average fall, $35 \mathrm{~mm}$. $\mathrm{Hg}$ in first hour.

Average percentage fall, 65 per cent. in first hour. 
In group 2 the average fall of tension in the first hour was $46 \mathrm{~mm}$. $\mathrm{Hg}$ and the percentage fall was 69 per cent. It was also observed that the intra-ocular pressure started rising gradually after the first hour and reached the pre-treatment level within 4 to 8 hours. The results were shown in Table IV.

TABLE IV

Fall in Tension in Patients with Acute Glaucoma treated with Oral Glycerol (RANGE OF TENSION 61-76 MM. HG)

\begin{tabular}{|c|c|c|c|c|c|c|c|c|c|}
\hline \multirow[b]{2}{*}{$\begin{array}{c}\text { Age } \\
\text { (yrs) }\end{array}$} & \multirow[b]{2}{*}{ Sex } & \multirow[b]{2}{*}{ Eye } & \multicolumn{7}{|c|}{ Ocular Tension } \\
\hline & & & Zero hr & $1 \mathrm{hr}$ & $2 \mathrm{hrs}$ & $3 \mathrm{hrs}$ & $4 \mathrm{hrs}$ & $\begin{array}{l}\text { Fall in } \\
\text { Tension } \\
\text { in first } \mathrm{hr} \\
(\mathrm{mm} . \mathrm{Hg})\end{array}$ & $\begin{array}{l}\text { Percentage } \\
\text { Fall in } \\
\text { Tension } \\
\text { in first hr }\end{array}$ \\
\hline $\begin{array}{l}35 \\
38 \\
40 \\
50 \\
65\end{array}$ & $\begin{array}{l}F \\
F \\
F \\
M \\
F\end{array}$ & $\begin{array}{l}\mathbf{R} \\
\mathbf{R} \\
\mathbf{R} \\
\mathbf{R} \\
\mathbf{L}\end{array}$ & $\begin{array}{l}62 \\
62 \\
76 \\
65 \\
68\end{array}$ & $\begin{array}{l}18 \\
20 \\
22 \\
20 \\
21\end{array}$ & $\begin{array}{l}20 \\
24 \\
25 \\
20 \\
24\end{array}$ & $\begin{array}{l}20 \\
28 \\
25 \\
22 \\
24\end{array}$ & $\begin{array}{l}24 \\
38 \\
32 \\
24 \\
28\end{array}$ & $\begin{array}{l}44 \\
42 \\
54 \\
45 \\
47\end{array}$ & $\begin{array}{l}70 \\
67 \\
72 \\
69 \\
69\end{array}$ \\
\hline
\end{tabular}

Average fall, $46 \mathrm{~mm}$. $\mathrm{Hg}$ in first hour.

Average percentage fall, 69 per cent. in first hour.

(B) Eleven eyes suffering from acute glaucoma treated with Diamox tablets $250 \mathrm{mg}$. 3 times a day. This group was further divided into three groups as shown in Table V.

TABLE V

Cases of Acute Glaucoma treated with Diamox Tablets

\begin{tabular}{c|c|c|c}
\hline $\begin{array}{c}\text { Range of Tension } \\
\text { (mm. Hg) }\end{array}$ & $\begin{array}{c}\text { No. of } \\
\text { Eyes }\end{array}$ & $\begin{array}{c}\text { Range in Fall in } \\
\text { Tension in 24 hrs }\end{array}$ & $\begin{array}{c}\text { Percentage Fall in } \\
\text { Intra-ocular Pressure }\end{array}$ \\
\hline $46-50$ & 4 & $14-25$ & 38 \\
$56-60$ & 4 & $18-28$ & 40 \\
$61-65$ & 3 & $24-32$ & 47 \\
\hline
\end{tabular}

It was seen that the action of Diamox started in 60 to 90 minutes and that the maximum effect was seen in 3 to 5 hours and persisted for 8 to 12 hours.

(C) Seventeen eyes suffering from acute glaucoma were treated with Diamox tablets $250 \mathrm{mg}$. 3 times a day and pilocarpine drops 2 per cent. 6 times a day. These cases were also divided into four groups as shown in Table VI.

TABLE VI

Cases of Acute Glaucoma treated with Diamox Tablets and Pilocarpine 2 per cent. Drops

\begin{tabular}{c|c|c|c}
\hline $\begin{array}{c}\text { Range of Tension } \\
\text { (mm. Hg) }\end{array}$ & $\begin{array}{c}\text { No. of } \\
\text { Eyes }\end{array}$ & $\begin{array}{c}\text { Range in Fall in } \\
\text { Tension in 24 hrs } \\
\text { (mm. Hg) }\end{array}$ & $\begin{array}{c}\text { Percentage Fall in } \\
\text { Intra-ocular Pressure }\end{array}$ \\
\hline $46-50$ & 4 & $21-28$ & 46 \\
$51-55$ & 8 & $12-26$ & 57 \\
$56-60$ & 4 & $34-42$ & 55 \\
$61-65$ & 4 & 50 \\
\hline
\end{tabular}


(D) Seven eyes suffering from acute glaucoma treated with glycerol and Diamox tablets $250 \mathrm{mg}$. 3 times a day. It was found in all cases that after the initial fall in tension with glycerol, tension could be maintained within safe limits with Diamox tablets (12-18 mm. Hg) (Table VII).

TABLE VII

Cases of Acute Glaucoma treated with Glycerol and Diamox

\begin{tabular}{|c|c|c|c|c|c|c|c|c|c|c|c|}
\hline \multirow{2}{*}{$\begin{array}{c}\text { Age } \\
\text { (yrs) }\end{array}$} & \multirow{2}{*}{ Sex } & \multicolumn{10}{|c|}{ Ocular Tension } \\
\hline & & Zero hr & $1 \mathrm{hr}$ & $2 \mathrm{hrs}$ & $3 \mathrm{hrs}$ & $4 \mathrm{hrs}$ & $8 \mathrm{hrs}$ & $12 \mathrm{hrs}$ & $24 \mathrm{hrs}$ & $48 \mathrm{hrs}$ & $72 \mathrm{hrs}$ \\
\hline $\begin{array}{l}65 \\
60 \\
30 \\
35 \\
50 \\
35 \\
40\end{array}$ & $\begin{array}{l}\mathbf{F} \\
\mathbf{F} \\
\mathbf{F} \\
\mathbf{M} \\
\mathbf{M} \\
\mathbf{F} \\
\mathbf{M}\end{array}$ & $\begin{array}{l}55 \\
48 \\
58 \\
57 \\
55 \\
62 \\
76\end{array}$ & $\begin{array}{l}19 \\
18 \\
19 \\
16 \\
20 \\
18 \\
22\end{array}$ & $\begin{array}{l}20 \\
18 \\
20 \\
18 \\
22 \\
20 \\
22\end{array}$ & $\begin{array}{l}20 \\
20 \\
19 \\
18 \\
23 \\
24 \\
20\end{array}$ & $\begin{array}{l}21 \\
18 \\
17 \\
21 \\
20 \\
18 \\
18\end{array}$ & $\begin{array}{l}16 \\
16 \\
20 \\
20 \\
18 \\
18 \\
18\end{array}$ & $\begin{array}{l}16 \\
15 \\
15 \\
17 \\
16 \\
18 \\
17\end{array}$ & $\begin{array}{l}14 \\
13 \\
14 \\
15 \\
15 \\
16 \\
15\end{array}$ & $\begin{array}{l}14 \\
12 \\
12 \\
15 \\
14 \\
17 \\
18\end{array}$ & $\begin{array}{l}15 \\
12 \\
11 \\
13 \\
12 \\
17 \\
18\end{array}$ \\
\hline
\end{tabular}

(E) Seven eyes suffering from acute glaucoma were treated with oral glycerol, Diamox tablets $250 \mathrm{mg}$. 3 times a day, and pilocarpine drops 2 per cent. 6 times a day. It was found that after the initial fall of tension, the intra-ocular pressure was maintained between 10 and $18 \mathrm{~mm} . \mathrm{Hg}$ in most of the cases (Table VIII).

TABLE VIII

Cases of Acute Glaucoma treated with Glycerol, Diamox Tablets, and Pilocarpine Drops

\begin{tabular}{c|c|c|c|c|c|c|c|c|c|c|c}
\hline \multirow{2}{*}{$\begin{array}{c}\text { Age } \\
\text { (yrs) }\end{array}$} & Sex & \multicolumn{10}{c}{ Intra-ocular Tension } \\
\cline { 3 - 11 } & & Zero hr & 1 hr & 2 hrs & 3 hrs & 4 hrs & 8 hrs & 12 hrs & 24 hrs & 48 hrs & 72 hrs \\
\hline 65 & F & 60 & 22 & 20 & 18 & 16 & 16 & 13 & 12 & 10 & 10 \\
40 & F & 58 & 16 & 16 & 20 & 20 & 18 & 15 & 13 & 12 & 10 \\
42 & M & 49 & 25 & 23 & 23 & 20 & 18 & 14 & 12 & 14 & 14 \\
50 & M & 48 & 14 & 14 & 15 & 15 & 10 & 10 & 12 & 13 & 13 \\
52 & M & 50 & 15 & 13 & 11 & 11 & 8 & 10 & 13 & 10 & 8 \\
38 & F & 62 & 20 & 18 & 18 & 16 & 13 & 15 & 12 & 10 & 10 \\
50 & F & 65 & 20 & 15 & 15 & 17 & 19 & 19 & 16 & 18 & 18 \\
\hline
\end{tabular}

Side-effects.-Mild headache and pain in the back of the neck, which lasted for 10 to 15 minutes and 5 minutes respectively, started 15 minutes after administration of the glycerol. In two glaucomatous patients nausea and vomiting occurred after the administration of the oral glycerol. No toxicity was observed with single dose treatment.

\section{Discussion}

In this study the effect of oral glycerol was seen in normal and glaucomatous eyes. Glycerol has been used as a single-dose treatment in acute glaucomatous eyes and also its effect has been noted in combination with Diamox $250 \mathrm{mg}$. tablets 3 times a day for 3 days, and pilocarpine 2 per cent. drops 6 times a day for 3 days. It was observed that the oral glycerol reduced ocular tension both in normal and in acute 
glaucomatous eyes. The maximum fall of tension was attained in the first hour but returned to the pre-treatment level at the end of the fourth hour.

The average percentage of fall in intra-ocular pressure in normal eyes in patients over 40 was 47 per cent. and below 40 it was 49 per cent. with the tension ranging from $12 \mathrm{~mm}$. $\mathrm{Hg}$ to $24 \mathrm{~mm}$. $\mathrm{Hg}$ (Tables I and II). Thus the fall of tension was greater in the younger group.

In cases of acute glaucoma with tensions of 48 to $60 \mathrm{~mm}$. $\mathrm{Hg}$ treated with oral glycerol, the percentage fall of tension was 65 per cent. In eyes with tensions of 61 to $76 \mathrm{~mm}$. Hg the percentage fall was 69 per cent. (Tables III and IV).

In cases of acute glaucoma treated with Diamox tablets only, the tension ranging from 46 to $50 \mathrm{~mm}$. $\mathrm{Hg}$, the average percentage fall was 38 per cent. In eyes with tensions of 56 to $60 \mathrm{~mm}$. Hg the percentage fall was 40 per cent., and in eyes with tensions from 61 to $65 \mathrm{~mm}$. $\mathrm{Hg}$, the percentage fall was 47 per cent. (Table V).

It is evident that the reduction in tension with Diamox therapy was $38-47$ per cent. in 24 hours. The effect of the drug was noticeable in 60-90 minutes and maximum in 3-5 hours, lasting for 8-12 hours.

The drug takes a longer time to act and the fall in tension is not so remarkable as with glycerol.

In cases of acute glaucoma treated with Diamox and pilocarpine drops 2 per cent., the average fall of tension was 46 per cent. in eyes with tensions of 46 to $50 \mathrm{~mm}$. $\mathrm{Hg}$; 57 per cent. in tensions from 51 to $55 \mathrm{~mm}$. $\mathrm{Hg}$; 55 per cent. with the tension ranging from 56 to $60 \mathrm{~mm}$. $\mathrm{Hg}$; and 50 per cent. with the tension ranging from 61 to $65 \mathrm{~mm}$. $\mathrm{Hg}$ in 24 hours (Table VI). Thus Diamox combined with pilocarpine 2 per cent. drops was more effective in reducing the intra-ocular pressure than Diamox alone.

In cases of acute glaucoma treated with a single dose of oral glycerol and Diamox tablets $250 \mathrm{mg}$. 3 times a day for 3 days, tension was maintained between 12 and $18 \mathrm{~mm}$. $\mathrm{Hg}$ for 72 hours (Table VII).

In cases of acute glaucoma treated with a single dose of glycerol, Diamox tablets (250 mm.), and pilocarpine 2 per cent. drops for 3 days, the tension was maintained between 10 and $18 \mathrm{~mm}$. Hg for 72 hours (Table VIII).

From the above study it is concluded that the best effect with oral glycerol was obtained when it was combined with Diamox tablets and pilocarpine drops 2 per cent. After the initial fall the tension could be maintained within normal limits for 72 hours.

Glycerol is one of the dehydrating agents which has strong osmotic properties. Many other dehydrating agents, such as dextrose, sucrose, magnesium sulphate, sorbitol, and mannitol have been frequently tried (Virno and others, 1963); Javid and Settlage (1956) used intravenous urea. None of them is free from complications and side-effects, such as anorexia, nausea, and vomiting (Grollman and Grollman, 1959), or changes in the electrocardiogram (Crews and Davidson, 1961). Davis, Duehr, and Javid (1961) noted hardening and local thrombosis of the vein of entry, and Watkins, Stubbs, and Lewin (1961) described tissue necrosis when urea accidentally extravasated into the subcutaneous tissue. Lastly, urea is of limited value in patients with impaired hepatic or renal function (Virno and others, 1963). The side-effects are, for the most part, bound up with the intravenous administration of the drugs mentioned, a route of administration which considerably limits their 
use in ophthalmology. Slow intravenous infusion proves disturbing to the patients. Oral glycerol is practically free from all the complications and drawbacks and the side-effects, except slight nausea and vomiting, which occurred in only a few cases.

Oral glycerol brought the tension of every acute glaucomatous eye down to normal limits within an hour, and the lowered tension could be maintained with Diamox tablets and pilocarpine drops 2 per cent. for 72 hours. Thus the eyes were saved from the acute effects of raised intra-ocular pressure. There is less chance of formation of peripheral anterior synechiae, as constriction of the pupil also occurs within 2-4 hours. Subsequently the angle of filtration could be examined easily and operation could be planned.

Surgical interference could easily be postponed for 2 to 3 days, by which time the eye had become quieter and the chances of complications during and after the operation minimized. The alarming symptoms of acute glaucoma, like pain, headache, and sudden diminution of vision, are controlled within an hour. The treatment of choice in acute glaucoma is oral glycerol with Diamox tablets by mouth, with pilocarpine 2 per cent. drops.

\section{Summary}

A total of 95 eyes was studied, 38 control and 57 with acute glaucoma. The effect of oral glycerol on the intra-ocular pressure of normal eyes and eyes with acute (closed-angle) glaucoma has been studied. The combined use of oral glycerol, Diamox tablets, and pilocarpine drops 2 per cent. gave the best results.

\section{REFERENCES}

Casey, T. A., and Trevor-Roper, P. D. (1963). Brit. med. J., 2, 851.

Crews, S. J., and Davidson, S. I. (1961). Brit. J. Ophthal., 45, 769.

Davis, M. D., Duehr, P. A., and JAVID, M. (1961). Arch. Ophthal. (Chicago), 65, 526.

Drance, S. M. (1964). Ibid., 72, 491.

Grollman, E. F., and Grollman, A. J. (1959). J. clin. Invest., 38, 749.

JaVID, M., and Settlage, P. (1956). J. Amer. med. Ass., 38, 749.

Thomas, R. P. (1963). Arch. Ophthal. (Chicago), 70, 625.

Virno, M., CANTORE, P., BietTI, C., and BucCI, M. G. (1963). Amer. J. Ophthal., 55, 1133.

Watkins, E. S., StubBS, J. D., and LeWIN, W. (1961). Lancet, 1, 358. 